\title{
The Short-Run Performance of IPOs of Privately Owned and Publicly Owned Firms: A Note from Australia
}

\author{
Adam Steen \\ Monash University, Australia \\ Petko Kalev \\ Monash University, Australia \\ Keith Turpie \\ Swinburne University of Technology, Australia
}

\begin{abstract}
This article builds on an earlier study by Choi and Nam (1998) on the initial price performance of Public Sector Initial Public Offerings PIPOs in 30 countries. They report that, in general, PIPOs are more underpriced than private sector IPOs. Our study of the Australian market suggests the opposite is the case. The difference in the underpricing between their study and the evidence presented here is most likely due to the characteristics of Australian PIPOs. These characteristics include the tender process adopted, the extensive marketing employed and the dominant position of many of the issuers (JEL G32).
\end{abstract}

Keywords: initial public offerings, initial return, privatization.

\section{Introduction}

In a recent edition of this journal, Choi and Nam (1998) compared the initial returns of Privatization Initial Public Offerings (PIPOs) to private-sector IPOs. Their sample included 185 privatizations in 30 countries. They found that PIPOs were on average more underpriced than IPOs of privately-owned enterprises.

One of the countries included in their sample was Australia. They report that their sample of seven Australian PIPOs, covering the period 1991-97, had an average initial return of 16.6 percent. They then eompared their publie seetor sample to a sample of 266 privately issued IPOs covering the period 1976-89 and reported an average initial return

(Multinational Finance Journal, 2001, vol. 5, no. 2, pp. 149-154)

(C) by the Multinational Finance Society, a nonprofit corporation. All rights reserved.

DOI: $10.17578 / 5-2-4$ 
of 11.9 percent. These two sample periods, however, covered vastly different market conditions and regulatory regimes. ${ }^{1}$ While the difference between returns was statistically insignificant, we propose that, if the same sample period was used, average initial returns would be different from those reported by Choi and Nam.

\section{Australian Public Sector IPOs}

Evidence on Australian PIPOs is limited to Easton and Pinder (1996), Breda et al. (1997), Lee et al. (1999) and Steen and Kendall (2001). Easton and Pinder (1996) found that for seven Australian PIPOs from August 1989 to July 1995, the average return on the first day's trading was 8.3 percent, while the cumulative 10-day return was 7.3 percent. They concluded that these PIPOs were no more underpriced than nonpublic sector IPOs. Choi and Nam compared the underpricing of their PIPO sample with the returns of private-sector IPOs calculated by Finn and Higham (1988) and Taylor and Walter (1991), whose samples related to the years 1966-1978 and 1977-1986, respectively.

In a recent study, Lee et al. (1999) indicated Australian PIPOs were underpriced and outperformed the market index over the long-run. The study did not compare the performance of Australian PIPOs to privatesector IPOs, hence there was no mention of the relative performance of the two groups. Further, Breda et al. (1997) compared 6 Australian PIPOs to only 20 private sector IPOs which represented different industries to those of the public-sector sample. Considering only the first 10-day's post-listing performance, they found that returns for private-sector IPOs exceeded those of Australian PIPOs.

Because of the shortcoming identified in the above Australian studies, we compare the returns of all Australian PIPOs to all privatesector IPOs listed on the Australian Stock Exchange (ASX) over the same sample period. The sample is the same as that used in Steen and Kendall (2001), and consists of 185 IPOs, including 8 PIPOs, from August 1,1989 to June 30, 1998, the period from the first Australian PIPO, the Australian Industry Development Corporation (AIDC), in

1. The introduction in 1991 of the Corporations Law Act raised the regulatory burden on issuers in Australia. Issues made subsequent to this date have been associated with significantly less underpricing. 
August 1989. ${ }^{2}$ The eight PIPOs averaged a mean return of 10.21 percent (standard deviation 12.45 percent) while the 177 private-sector IPOs returned 17.32 percent (standard deviation 54.91 percent). ${ }^{3} \quad$ While consistent with those of Breda et al. (1997), these figures are quite different to those reported by Choi and Nam (1998). The most likely reason for this is that the time periods covered by their private-sector IPO sample and their PIPO sample do not correspond.

As mentioned above, Choi and Nam (1998) found that, in general, over their sample of 30 countries, PIPOs were more underpriced than private-sector IPOs. Their paper focused on the underpricing across many markets and did not investigate the particular characteristics of any specific IPO market. An analysis of these characteristics may account for the difference in the initial returns of Australian PIPOs and PIPOs of other countries. For example, Breda et al. (1997) suggested, the tender process adopted by Australian governments (federal and state) aimed to achieve the highest possible price to meet budget forecasts. Further, Choi and Nam (1998) indicated that all of the Australian firms in their sample were offered at fixed price. While this is true for most Australian IPOs, more recent issues have applied a constrained (book-building) approach. Under this approach the application price of retail subscribers was fixed before institutional investors submitted their bids. The final price for all investors was determined as a result of this pre-listing price testing and excess subscription money was refunded to retail investors after the final price had been determined. Interestingly, only four of the Australian PIPOs were offered at fixed price as shown in table 1. This implies that retail

2. The sample includes all new public companies and private companies going public for the first time. Re-listings or refloats, firms that were listed once, reverted to private ownership and then floated again, were excluded as were issues that were not independent of other listed and/or foreign companies and firms listed/registered on a foreign stock exchange before being admitted to the ASX official list. In addition, companies listed via a Scheme of Arrangement or the issue of an Information Memorandum were excluded as no new shares are issued. Explanatory Memorandums, debt issues, issues of convertible notes, transfers to the main board from the second board, listings as a result of capital reconstructions, seasoned issues and issues where the prospectus was not registered were similarly excluded. Mining and oil IPOs were also excluded as none of the public sector IPOs were mining or oil companies. Our sample of PIPOs covers all Australian PIPOs issued from August 11989 to June 301998.

3. Initial returns are adjusted for market movements and are calculated in the same way as Choi and Nam (1998) using the formula (Closing Price - Offer Price)/Offer Price. 
TABLE 1. Price Setting Mechanism of Australian PIPOs

\begin{tabular}{|c|c|}
\hline $\begin{array}{l}\text { Privatization } \\
\text { Company Name }\end{array}$ & $\begin{array}{l}\text { Price Setting } \\
\text { Mechanism }\end{array}$ \\
\hline AIDC Limited & Fixed Price \\
\hline Commonwealth Bank of Australia Limited & Fixed Price \\
\hline GIO Australia Holdings Limited & Constrained Opening Price \\
\hline SGIO Insurance Limited & Fixed Price \\
\hline CSL Limited & Constrained Opening Price \\
\hline Tabcorp Holdings Limited & Constrained Opening Price \\
\hline Qantas Airways Limited & Constrained Opening Price \\
\hline Bank of Western Australia Limited & Fixed Price \\
\hline Telstra Corporation Limited & Constrained Opening Price \\
\hline TAB Limited & Constrained Opening Price \\
\hline
\end{tabular}

Source: Lee et. al., 1999

investors paid a different subscription price to institutional investors in he floats of Qantas, Telstra, Tabcorp and TAB. ${ }^{4}$

In addition, with Australian PIPOs, "the marketing to the financial and investment community was intense and the information generated as a result was substantial" (Breda et al. 1997, p. 22). As the period of time between opening and closing of applications was greater for PIPOs, than private-sector IPOs, the information asymmetry should be lower between informed and uninformed investors, and hence underpricing less. Furthermore, because public-sector issues were larger than private-sector issues their risk, hence return, should have been lower. ${ }^{5}$ Several of these Australian PIPOs were in a dominant position within particular industries. For example, the Commonwealth Serum Laboratories (CSL) was the exclusive manufacturer of plasmaderived products in Australia. At the time of listing, national telecommunications company, Telstra, accounted for 95 percent of the ASX telecommunications sub-index. Some other PIPOs were not in a dominant market position. Venture capital provider, the AIDC, and regional bank, Bank WA, accounted for only a small part of the finance industry. Similarly, United Energy was one of a number of energy providers of which several, such as Australian Gas Light (AGL),

4. Although GIO and CSL were constrained opening price offerings retail and institutional investors paid the same offer price.

5. See Banz (1981), for further discussion. 
dominated. ${ }^{6}$

The Australian government attempted to ensure that small retail investors received an allocation of PIPOs by scaling back share parcels in the event excess applications were received. Quite often, the Australian government specified a maximum amount of the issue to be set aside for institutional investors. According to Steen and Kendall (2001), excess demand above this amount would have to be met by postlisting purchases.

Given the above discussion it could be said that PIPOs are less underpriced than IPOs. Using the same sample period (1991 to 1997) and the method of calculating returns as Choi and Nam (1998), we find that Australian PIPOs have mean initial returns of 11.57 percent or 10.25 percent depending on whether retail or institutional prices are used. This compares to 17.55 percent for all Australian private-sector IPOs covering the same sample period. These figures are quite different from those reported by Choi and Nam (1998). While the standard deviation of initial returns for PIPOs is 17.09 and 16.27 percent (retail and institutional prices, respectively) the equivalent figure for privatesector IPOs is 55.49 percent, roughly three times the size. These figures are consistent with exiting IPO literature that generally supports the notion that risk and return should be positively-related. Hence, PIPOs have significantly lower risk and therefore lower initial return than private sector IPOs.

No further statistical inference can be drawn by comparing the difference in mean initial returns of private sector IPOs and PIPOs. Firstly, initial returns are highly dispersed as indicated by their standard deviation thus invalidating traditional $t$-tests for equality of means. Secondly, the sample size of PIPOs is not large enough to undertake resampling procedures, such as those proposed by Lyon, Barber and Tsai (1999). Thirdly, we are unable to match PIPOs to private-sector IPOs in terms of industry or size. For example, Telstra and Commonwealth Bank of Australia were by far larger in terms of market capitalization and amount raised than any other private-sector IPO during the sample period.

6. While Bank WA and United Energy were sold prior to floating they have been included in some studies as Australian PIPOs. See Steen and Kendall (2001) for a further discussion. 


\section{Conclusion}

Although Choi and Nam (1998) report that Australian PIPOs are more underpriced than private sector IPOs, the results presented above suggest the contrary. The difference in the underpricing between their study and the evidence presented here is most likely due to the characteristics of Australian PIPOs. These characteristics include the tender process adopted, the extensive marketing employed and the dominant position of many of the issuers.

\section{References}

Banz, R.W. 1981. The relationship between return and market value of common stocks. Journal of Financial Economics 9(1):3-18.

Breda, E.; Collis, R.; Deed, B.; and Psevdos, N. 1997. Bargain buys: Why Australian government IPOs are not as cheap as some. JASSA (Summer): 17-23.

Bruce, R; McKern. B; Pollard, I.; and Skully, M. 1997. Handbook of Australian Corporate Finance, $5^{\text {th }}$ ed., Butterworths, Sydney.

Choi, S., and Nam, S. 1998. The short-run performance of IPOs of privately and publicly-owned firms: International evidence. Multinational Finance Journal 2(3): 225-244.

Easton, S.A., and Pinder, S.M. 1996. Pricing of Australian government sector IPO. Journal of Applied Finance and Investment 1(1): 40-42.

Finn, F.J., and Higham, R. 1988. The performance of unseasoned new equity issues-cum-stock exchange listings in Australia. Journal of Banking and Finance 12: 333-351.

Lee, P.J.; Steiner, N.; Taylor, S.; and Walter, T.S. 1999. Australian share issue privatizations: Balancing finance and politics. University of Sydney, Department of Accounting and Finance, Mimeo.

Lyon, J.D.; Barber, B.M.; and Tsai, C-L. 1999. Improved methods for tests of long-run abnormal stock returns. Journal of Finance 54(1): 165-210.

Steen, A.B. 1997. Initial public offerings in Australia 1984-1994: Influences on the pricing of new issues. Ph.D. Thesis, LaTrobe University.

Steen, A.B., and Kendall, K. 2001. The long-run performance of privatized government monopolies: Australian evidence. Managerial Finance Forthcoming.

Taylor, S., and Walter, T. (1991) Australian IPO underpricing: Institutional aspects and the winner's curse. Working Paper, Department of Accounting, University of Sydney. 